\title{
Use of Non-Conventional Chemicals against Early Blight of Potato (Solanum tuberosum) Caused by Alternaria solani
}

\author{
Dibakar Panda ${ }^{1}$, Ashish Chakraborty ${ }^{2}$, Ritesh Kumar ${ }^{2 *}$ and Saurav Govind Rao ${ }^{3}$ \\ ${ }^{1}$ Department of Plant Protection, Palli Siksha Bhavana, Visva Bharati, West Bengal, India \\ ${ }^{2}$ Department of Plant Pathology, Bidhan Chandra Krishi Viswavidyalaya, \\ Mohanpur, Nadia, West Bengal, India \\ ${ }^{3}$ Department of Plant Pathology, Chandra Shekhar Azad University of Agriculture and \\ Technology, Kanpur, Uttar Pradesh, India
}

*Corresponding author

\section{A B S T R A C T}

An experiment was conducted to find out efficacy of different non-conventional chemicals to manage the early blight disease in potato. Study was carried out with seven chemicals i.e. lithium sulphate, calcium chloride, oxalic acid, salicylic acid, iron sulphate, potassium bicarbonate and ascorbic acid in in vitro condition for their conidial germination efficacy against Alternaria solani. It was observed that, oxalic acid@ 1.0 ppm concentration exhibited highest per cent inhibition of conidial germination $(88.89 \%)$ over control after 24 hrs. The next best conidial germination inhibition $(75.00 \%)$ was observed in case of lithium sulphate@1ppm concentration. This was followed by potassium bicarbonate, where $71.43 \%$ conidial germination inhibition was observed @ 1 ppm concentration. In the field condition, also the oxalic acid @1 ml/ lit exhibited best result in terms of percent disease incidence $(32.62 \%)$, percent disease intensity $(24.32 \%)$ at 73 DAP and yield of tubers $(25.31 \mathrm{t} / \mathrm{ha})$ as compared to control treatment. The overall disease reduction in case of oxalic acid was $42.10 \%$ over control which was also highest compared to all other treatments.

\section{Introduction}

Potato (Solanum tuberosum L.) is an important food crop of the world. It is used as vegetable, stock feed and in industries for manufacturing starch, alcoholic beverages and other processed products. Potato is the world's fourth-largest food crop, after maize, wheat and rice. The crop is a native of South American continent from about 7000 to 9000 years ago. It was introduced in India by
Portuguese during early $17^{\text {th }}$ century. It has the global production of 482 lakh tonnes (GoI). Alone, India is producing over 45 million tonnes of potatoes, sharing more than $12 \%$ of the global production at an average productivity of 23 tonnes per hectare (201314) which is second only to China (Hussain, 2016). In India, the major Potato growing states are Uttar Pradesh, West Bengal, Bihar, Madhya Pradesh, Gujarat, Punjab, Assam, Haryana, Jharkhand, Chhattisgarh, Karnataka 
and Maharashtra. Potato plants are subjected to attack by numerous diseases wherever the crop is planted, some of which are widespread and others are localized. The causal agents of these diseases include fungi, bacteria, viruses, phytoplasmas, viroids and nematodes. Another group disorders, called non infectious diseases, include those due to unfavourable environment, faulty nutrition or other abiotic factors.

Among the diseases caused by fungal agents, early blight disease of potato caused by Alternaria solani is of major concern in potato production at present. Early blight (Alternaria solani) is a leaf-spot disease that occurs on potato leaves, stems and tubers. It is one of the most common annually occurring foliar diseases of potatoes in India. The pathogen was first described by Ellis \& Martin (1882) as Macrosporium solani. The symptoms were described by Chester (1892) in USA after the appearance of this pathogen on potatoes and other cultivated plants of the same family, particularly tomato and eggplant. He cleared that the progress of early blight was slower than that of late blight, caused by Phytophthora infestans. In 1893, Jones suggested the name 'early' blight to distinguish the disease from 'late' blight. $A$. solani is classified in the domain Eukaryota, kingdom Fungi, phylum Deuteromycota, class Hyphomycetes, order Hyphales.

Potato is the major crop on which farmers are dependant for production and their consumption in West Bengal. The production alone, in the state was 11234.80 MT in 201617 , with a share of $23.29 \%$ in the production of India (GoI). Early blight diseases in the crop cause a huge loss to the farming community. The primary infection occurs on older foliage early in the season and then the inoculum spreads to immature surfaces, such as to the younger leaves and young tubers under favourable weather conditions. The disease causes losses to crop productivity in the field and to tuber quality in storage. In stored condition also, potato losses may be substantial and reach $80 \%$ of tubers, affected by early blight lesions. In some instances, tuber infection has caused huge losses in potatoes stored for processing at temperature of $10^{\circ} \mathrm{C}$ or higher. Several effective fungicides have been recommended against this pathogen, but they are not considered to be long-term solutions, due to their huge cost, exposure risks, residues and other health and environmental hazards. In an attempt to modify this condition, some efforts have been made and a study was made to manage early blight of potato by some non-conventional chemicals.

\section{Materials and Methods}

The experiment was conducted to study the suitability and potentiality of Lithium sulphate (T1), Calcium chloride (T2), Oxalic acid (T3), Salicylic acid (T4), Iron sulphate (T5), Potassium bicarbonate (T6) and Ascorbic acid (T7) against the early blight disease in potato. The experiment was conducted in vitro as well as in the field condition. Mycelial disks of colonies grown in PDA (200 g of potato, $20 \mathrm{~g}$ of dextrose, $20 \mathrm{~g}$ of agar, $1 \mathrm{~L}$ of distilled water) of $A$. solani were transferred to Petri plates with PDA covered with sterilized pieces of filter paper $\left(\begin{array}{llll}1 & \mathrm{x} & 1 & \mathrm{~cm}\end{array}\right)$ (Dhingra and Sinclair, 1995). After full development of the colonies, the pieces of colonized filter paper were removed and stored at $-80^{\circ} \mathrm{C}$. Distilled water with $0.01 \%$ Tween 80 was used to harvest the conidia with a brush (Foolad et al., 2000). The conidial suspension was collected in beakers and its concentration was determined by counting the number of spores in a $10 \mu \mathrm{L}$-drop under the microscope (100X) and multiplying the number counted by 100 to estimate the total number of conidia/mL. The field experiment was conducted during the Rabi season at District seed farm "C" unit, 
B.C.K.V., Kalyani, West Bengal during 20162017 crop season. This Seed Farm is located at Latitude: $22^{\circ} 58^{\prime} 48^{\prime \prime}$ and Longitude: $88^{\circ} 26^{\prime}$ $24 "$ and $11 \mathrm{~m}$ altitude. The variety selected for the entire experiment was Kufri Jawahar. The meteorological data of the season are presented in table 1. For non-chemical management of early blight of potato under field condition, 24 plots were made, size of each plot measured about $3 \mathrm{~m} \times 2 \mathrm{~m}$, and number of treatments was 8 having 3 replications in each treatment using Randomised Block Design (Gomez and Gomez, 1984). Each plot was separated together by an irrigation channel of $0.5 \mathrm{~m}$ width. The fields were surrounded by bunds of $0.25 \mathrm{~m}$ width. An irrigation channel of about $0.5 \mathrm{~m}$ was situated at one side of the fields. The assay was done on the basis of Disease Incidence, Disease Intensity, Disease Reduction and yield.

\section{Results and Discussion}

Seven chemicals were evaluated in in-vitro as well as in field condition for their efficacy against Alternaria solani and the results of the present trial revealed that oxalic acid among all the chemicals used, significantly controls early blight in potato than control plots.

\section{Inhibition of conidial germination}

It is observed from the results presented in table 2 that oxalic acid (T3) @ 1.0 ppm concentration exhibited highest percent conidial germination inhibition $(88.89 \%)$ over control (T8) after $24 \mathrm{hrs}$. The next best conidia germination inhibition $(75.00 \%)$ was observed in case of lithium sulphate (T1) @ 1ppm concentration. This was followed by potassium bicarbonate (T6) where $71.43 \%$ conidial germination inhibition was observed @ 1 ppm concentration. In all other treatments like salicylic acid (T4), iron sulphate (T5) and calcium chloride (T2) the percent conidial germination inhibition over control was 66.67 , 45.46 and 33.34 respectively. Least percent conidial germination inhibition was observed in case of ascorbic acid (T7) in which only $27.80 \%$ conidia were inhibited. This finding is also supported by Ivanovic et al., (2002), who reported that potassium bicarbonate $(\mathrm{PBC})$ at four different concentrations $(0.5,1.0,2.0$ and $5.0 \mathrm{ppm}$ ) in in vitro condition shows inhibitory effects on conidial germination and mycelial growth of A. solani.

\section{Disease reduction and yield}

All the chemicals were also tested for their potentiality to control the early blight disease in the field condition and the results were similar to the in vitro test. The result presented in Table 3 clearly tells that oxalic acid (T3) @ $1 \mathrm{ml} /$ lit exhibited best result in terms of percent disease incidence (32.62\%) and percent disease intensity $(24.32 \%)$ at 73 DAP as compared to control treatment (T8) where per cent disease incidence was $51.29 \%$ and $42.00 \%$ respectively. The overall disease reduction was $42.10 \%$ over control which was also highest compared to all other treatments. Not only that, the total tuber yield was also highest i.e. $25.31 \mathrm{t} / \mathrm{ha}$. The relation between the yield against various treatments are shown in the figure 1. Among all other treatments, the next best result was obtained by treatment T1, where lithium sulphate @1g/lit resulted $34.95 \%$ disease reduction over control treatment with total production $24.79 \mathrm{t} / \mathrm{ha}$. This was followed by potassium bicarbonate (T6) with incidence and intensity per cent $37.00 \%$ and $29.50 \%$ respectively at 73 DAP. In this treatment percent disease reduction over control was $29.76 \%$ with total tuber yield $23.67 \mathrm{t} / \mathrm{ha}$. The next best result was obtained by treatment $\mathrm{T}_{4}$ where salicylic acid @ 1g/lt in terms of disease incidence $39.28 \%$ and percent disease intensity $31.49 \%$ at 73 DAP with total tuber yield $21.47 \mathrm{t} / \mathrm{ha}$. DMRT analysis (Table 4) indicates that the T3 is best among of all the 
treatments used for the inhibition of conidial disease reduction over control in the field germination over control and also for percent followed by T1 and T4 and T5.

\section{Table.1 Meteorological data during the period of experiment}

\begin{tabular}{|c|c|c|c|c|c|c|}
\hline \multirow{2}{*}{ Month } & \multicolumn{7}{c|}{ Weather parameters } \\
\cline { 2 - 7 } & \multicolumn{2}{|c|}{ Average } & Average & Average RH (\%) & Average \\
& Temperature $\left({ }^{\circ} \mathrm{C}\right)$ & rainfall & & & Sunshine \\
& Max & Min & $(\mathrm{mm})$ & Max & Min & hour \\
\hline December 2016 & 26.45 & 13.20 & 00.00 & 93.83 & 59.06 & 5.28 \\
\hline January 2017 & 26.80 & 10.94 & 00.00 & 91.25 & 49.67 & 5.56 \\
\hline February 2017 & 30.25 & 15.15 & 00.00 & 89.92 & 45.88 & 7.60 \\
\hline March 2017 & 31.96 & 17.86 & 00.00 & 91.50 & 49.00 & 8.67 \\
\hline
\end{tabular}

Source: Department of Agricultural Meteorology, Bidhan Chandra Krishi Vishwavidyalaya, Mohanpur, Nadia, West Bengal, India

\section{Table.2 Efficacy of chemicals on inhibition of conidial germination of Alternaria solani in in vitro condition}

\begin{tabular}{|c|c|c|c|}
\hline \multirow[t]{2}{*}{ Treatment } & Conc. (ppm) & $\begin{array}{c}\text { Conidia } \\
\text { germination }(\%)\end{array}$ & $\begin{array}{c}\text { Conidia } \\
\text { germination } \\
\text { inhibition over } \\
\text { control }(\%)\end{array}$ \\
\hline & & (24 hrs) & (24 hrs) \\
\hline $\mathrm{T1}$ & 1.00 & $28.57(32.63)^{*}$ & $75.00(60.33)$ \\
\hline $\mathrm{T} 2$ & 1.00 & $66.66(55.04)$ & $33.34(35.57)$ \\
\hline T3 & 1.00 & $11.11(19.92)$ & $88.89(70.99)$ \\
\hline $\mathrm{T4}$ & 1.00 & $33.33(35.57)$ & $66.67(55.04)$ \\
\hline $\mathrm{T5}$ & 1.00 & $54.54(47.89)$ & $45.46(42.68)$ \\
\hline T6 & 1.00 & $25.00(30.33)$ & $71.43(58.01)$ \\
\hline T7 & 1.00 & $72.20(58.50)$ & $27.80(32.14)$ \\
\hline $\mathrm{T} 8$ & - & 100 & $0.00(4.05)$ \\
\hline SEm \pm & & 1.06 & 1.11 \\
\hline $\mathrm{CD}(\mathrm{P}=0.05)$ & & 3.22 & 3.37 \\
\hline C.V (\%) & & 3.75 & 3.77 \\
\hline
\end{tabular}

* parenthesis for column 3 and 4 represents angular transformed values. 
Table.3 Efficacy of different chemicals used after onset of disease on management of early blight of potato under field condition

\begin{tabular}{|c|c|c|c|c|c|c|c|c|c|c|c|c|c|}
\hline \multirow{2}{*}{ Treatments } & \multirow{2}{*}{$\begin{array}{l}\text { Dose } \\
(\mathrm{g} / \mathrm{lt}) \\
\text { or } \\
(\mathrm{ml} / \mathrm{lt})\end{array}$} & \multicolumn{5}{|c|}{ Disease incidence (\%) } & \multicolumn{5}{|c|}{ Disease intensity (\%) } & \multirow[b]{2}{*}{$\begin{array}{c}\text { Percent } \\
\text { Disease } \\
\text { reduction } \\
\text { over } \\
\text { control } \\
(\%)\end{array}$} & \multirow[t]{2}{*}{ Yield (t/ha) } \\
\hline & & $\begin{array}{c}45 \\
\text { DAP }\end{array}$ & $\begin{array}{c}52 \\
\text { DAP }\end{array}$ & $\begin{array}{c}59 \\
\text { DAP }\end{array}$ & $\begin{array}{c}66 \\
\text { DAP }\end{array}$ & $\begin{array}{c}73 \\
\text { DAP }\end{array}$ & $\begin{array}{c}45 \\
\text { DAP }\end{array}$ & $\begin{array}{c}52 \\
\text { DAP }\end{array}$ & $\begin{array}{c}59 \\
\text { DAP }\end{array}$ & $\begin{array}{c}66 \\
\text { DAP }\end{array}$ & $\begin{array}{c}73 \\
\text { DAP }\end{array}$ & & \\
\hline T1 & 1 & $\begin{array}{c}27.29 \\
(31.48)\end{array}$ & $\begin{array}{c}28.36 \\
(32.16)\end{array}$ & $\begin{array}{c}30.45 \\
(33.48)\end{array}$ & $\begin{array}{c}31.98 \\
(34.42)\end{array}$ & $\begin{array}{c}35.60 \\
(36.62)\end{array}$ & $\begin{array}{c}14.43 \\
(22.32)\end{array}$ & $\begin{array}{c}17.30 \\
(24.57)\end{array}$ & $\begin{array}{c}21.41 \\
(27.55)\end{array}$ & $\begin{array}{c}24.30 \\
(29.52)\end{array}$ & $\begin{array}{c}27.32 \\
(31.50)\end{array}$ & 34.95 & 24.79 \\
\hline T2 & 1 & $\begin{array}{c}32.47 \\
(34.72)\end{array}$ & $\begin{array}{c}35.38 \\
(36.48)\end{array}$ & $\begin{array}{c}38.94 \\
(38.59)\end{array}$ & $\begin{array}{c}41.67 \\
(40.19)\end{array}$ & $\begin{array}{c}48.79 \\
(44.29)\end{array}$ & $\begin{array}{c}22.29 \\
(28.16)\end{array}$ & $\begin{array}{c}26.46 \\
(30.94)\end{array}$ & $\begin{array}{c}29.86 \\
(33.11)\end{array}$ & $\begin{array}{c}34.40 \\
(35.90)\end{array}$ & $\begin{array}{c}37.10 \\
(37.51)\end{array}$ & 11.67 & 20.49 \\
\hline T3 & 1 & $\begin{array}{c}24.14 \\
(29.41)\end{array}$ & $\begin{array}{c}26.49 \\
(30.96)\end{array}$ & $\begin{array}{c}28.94 \\
(32.53)\end{array}$ & $\begin{array}{c}29.80 \\
(33.07)\end{array}$ & $\begin{array}{c}32.62 \\
(34.81)\end{array}$ & $\begin{array}{c}14.29 \\
(22.20)\end{array}$ & $\begin{array}{c}15.80 \\
(23.41)\end{array}$ & $\begin{array}{c}19.19 \\
(25.97)\end{array}$ & $\begin{array}{c}21.86 \\
(27.86)\end{array}$ & $\begin{array}{c}24.32 \\
(29.53)\end{array}$ & 42.10 & 25.31 \\
\hline T4 & 1 & $\begin{array}{c}29.90 \\
(33.13)\end{array}$ & $\begin{array}{c}30.42 \\
(33.46)\end{array}$ & $\begin{array}{c}32.45 \\
(34.71)\end{array}$ & $\begin{array}{c}34.52 \\
(35.97)\end{array}$ & $\begin{array}{c}39.28 \\
(38.79)\end{array}$ & $\begin{array}{c}18.54 \\
(25.49)\end{array}$ & $\begin{array}{c}22.71 \\
(28.45)\end{array}$ & $\begin{array}{c}26.83 \\
(31.18)\end{array}$ & $\begin{array}{c}27.51 \\
(31.62)\end{array}$ & $\begin{array}{c}31.49 \\
(34.12)\end{array}$ & 25.02 & 21.47 \\
\hline T5 & 1 & $\begin{array}{c}31.24 \\
(33.97)\end{array}$ & $\begin{array}{c}32.87 \\
(34.97)\end{array}$ & $\begin{array}{c}35.10 \\
(36.31)\end{array}$ & $\begin{array}{c}37.76 \\
(37.90)\end{array}$ & $\begin{array}{c}41.26 \\
(39.95)\end{array}$ & $\begin{array}{c}19.30 \\
(26.05)\end{array}$ & $\begin{array}{c}23.13 \\
(28.73)\end{array}$ & $\begin{array}{c}27.19 \\
(31.41)\end{array}$ & $\begin{array}{c}29.26 \\
(32.73)\end{array}$ & $\begin{array}{c}34.10 \\
(35.71)\end{array}$ & 18.81 & 21.39 \\
\hline T6 & 1 & $\begin{array}{c}28.24 \\
(32.09)\end{array}$ & $\begin{array}{c}29.84 \\
(33.10)\end{array}$ & $\begin{array}{c}31.40 \\
(34.07)\end{array}$ & $\begin{array}{c}33.60 \\
(35.41)\end{array}$ & $\begin{array}{c}37.00 \\
(37.45)\end{array}$ & $\begin{array}{c}16.37 \\
(23.86)\end{array}$ & $\begin{array}{c}21.45 \\
(27.58)\end{array}$ & $\begin{array}{c}24.65 \\
(29.76)\end{array}$ & $\begin{array}{c}26.19 \\
(30.77)\end{array}$ & $\begin{array}{c}29.50 \\
(32.88)\end{array}$ & 29.76 & 23.67 \\
\hline T7 & 1 & $\begin{array}{c}31.58 \\
(34.18)\end{array}$ & $\begin{array}{c}32.16 \\
(34.53)\end{array}$ & $\begin{array}{c}37.06 \\
(37.48)\end{array}$ & $\begin{array}{c}40.25 \\
(39.36)\end{array}$ & $\begin{array}{c}43.60 \\
(41.31)\end{array}$ & $\begin{array}{c}19.62 \\
(26.28)\end{array}$ & $\begin{array}{c}24.07 \\
(29.37)\end{array}$ & $\begin{array}{c}28.19 \\
(32.05)\end{array}$ & $\begin{array}{c}31.19 \\
(33.93)\end{array}$ & $\begin{array}{c}35.97 \\
(36.84)\end{array}$ & 14.36 & 20.94 \\
\hline T8 & 1 & $\begin{array}{c}33.21 \\
(35.17)\end{array}$ & $\begin{array}{c}35.42 \\
(36.51)\end{array}$ & $\begin{array}{c}40.19 \\
(39.33)\end{array}$ & $\begin{array}{c}43.95 \\
(41.51)\end{array}$ & $\begin{array}{c}51.29 \\
(45.72)\end{array}$ & $\begin{array}{c}23.96 \\
(29.29)\end{array}$ & $\begin{array}{c}28.20 \\
(32.06)\end{array}$ & $\begin{array}{c}32.52 \\
(34.75)\end{array}$ & $\begin{array}{c}36.76 \\
(37.31)\end{array}$ & $\begin{array}{c}42.00 \\
(40.38)\end{array}$ & 00 & 18.41 \\
\hline $\operatorname{Sem}( \pm)$ & & 0.56 & 0.59 & 0.65 & 0.69 & 0.78 & 0.353 & 0.42 & 0.50 & 0.55 & 0.62 & & 0.42 \\
\hline $\begin{array}{c}\text { C.D } \\
(\mathbf{P}=\mathbf{0 . 0 5})\end{array}$ & & 1.61 & 1.69 & 1.86 & 1.99 & 2.23 & 1.014 & 1.21 & 1.43 & 1.57 & 1.79 & & 1.22 \\
\hline C.V. & & 3.27 & 3.25 & 3.27 & 3.28 & 3.27 & 3.289 & 3.27 & 3.28 & 3.27 & 3.29 & & 3.31 \\
\hline
\end{tabular}


Table.4 Duncan's Multiple Range test $(\mathrm{p} \leq \mathbf{0 . 0 5})$ to delineate conidial germination inhibition and percent disease reduction over control

\begin{tabular}{|c|c|c|}
\hline Treatments & $\begin{array}{c}\text { Conidial germination inhibition } \\
\text { over control }\end{array}$ & $\begin{array}{c}\text { Percent disease reduction over } \\
\text { control }\end{array}$ \\
\hline T1 & $75 \mathrm{bc}$ & $34.95 \mathrm{~b}$ \\
\hline T2 & $33.34 \mathrm{f}$ & $11.67 \mathrm{~g}$ \\
\hline T3 & $88.89 \mathrm{a}$ & $42.10 \mathrm{a}$ \\
\hline T4 & $66.67 \mathrm{~d}$ & $25.02 \mathrm{~cd}$ \\
\hline T5 & $45.46 \mathrm{e}$ & $18.81 \mathrm{ef}$ \\
\hline T6 & $71.43 \mathrm{bc}$ & $29.76 \mathrm{bc}$ \\
\hline T7 & $27.80 \mathrm{~g}$ & $14.36 \mathrm{ef}$ \\
\hline T8 & $0 \mathrm{~h}$ & $0 \mathrm{~h}$ \\
\hline
\end{tabular}

Values with different letters show significant difference $(P \leq 0.05)$ as determined by DMRT. Same letters depict the non-significant results
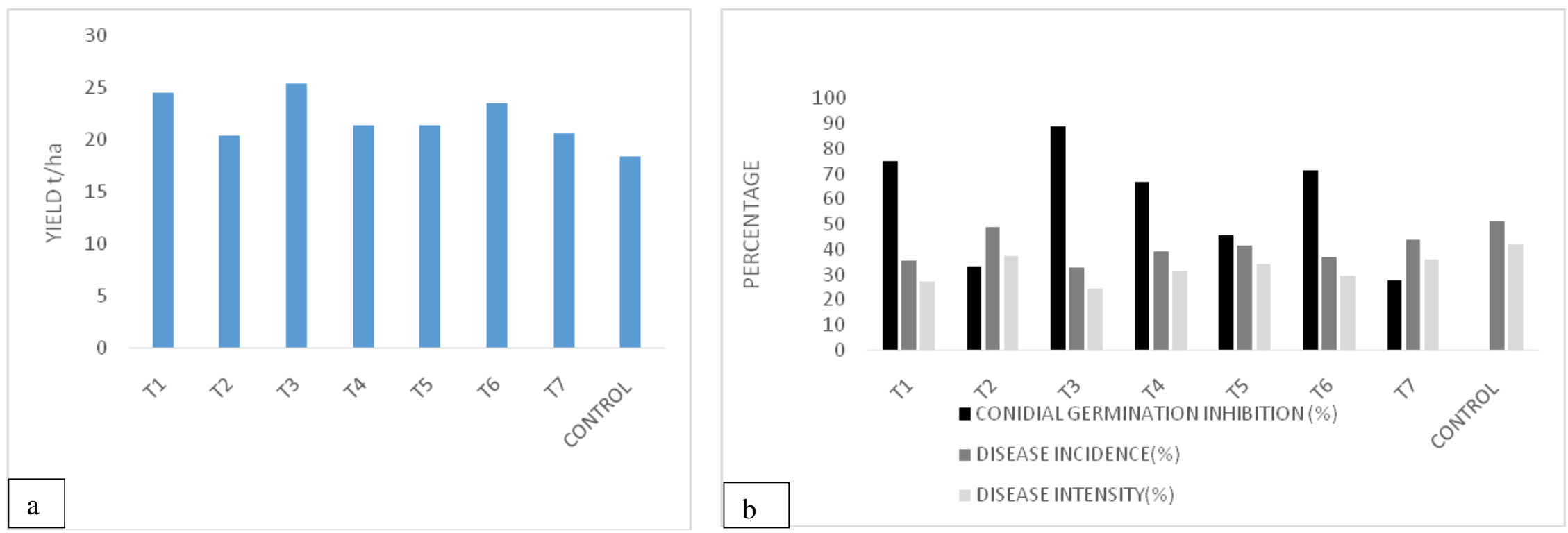

Fig.1 a) yield of tuber against different treatments in the field. b) conidial germination inhibition in vitro, Disease incidence and Disease intensity after 73 DAP for various treatments 
This finding is also supported by Maity et al., (2005) who observed that groundnut seedling dip treatment in metal salts, amino acids and growth regulator solutions at low concentrations gave disease free plants against leaf spot and is cost effective. This experiment also establishes the fact that use of such chemicals at low concentration can provide strong and lasting protection as dynamic defence mechanism. Similarly, Olivier et al., (1998) also reported that the radial growth of $A$. solani was significantly reduced $(p<0.05)$ by various organic and inorganic salts concentrations used for the management of silver scurf disease on potato tubers.

Various workers also reported about the management of plant diseases using nonconventional chemicals against various pathogens. Bag and Singh (1997) reported that the use of barium sulphate, lithium sulphate, manganese sulphate, cupric chloride, ferric chloride are substantially (61$77 \%$ ) able to inhibit disease symptoms and reduce plant mortality by 45 to $75 \%$ in comparison to control in case of foot rot of soyabean. Dasgupta et al., (2000) reported that mercuric chloride, barium sulphate, ferric chloride, barium nitrate and zinc chloride can control collar rot disease of groundnut caused by Aspergillus niger up to 50 to $66.5 \%$.

Calcium, magnesium levels are generally increased and specific polygalacturonase activity decreases in the plants treated with non-conventional chemicals as compared to untreated one (Mitra and Chowdhury, 2001). Reduction in oxalic acid content might be the reason by which non-conventional chemicals induces resistances (Faboya et al., 1983). Also the increased level of calcium and magnesium leads to transformation of enzyme-sensitive cell wall pectic components, which act as a dynamic resistance factor around the lesion sites. Effective compounds for plant disease management should activates the defense potentialities of the plants, so that it become a competent and ready to interact with the challenger pathogen as like the resistant plant behaves through their natural defense response. Thus, from the present study we can conclude that by using nonconventional chemicals namely Lithium sulphate, Calcium chloride, Oxalic acid, Salicylic acid, Iron sulphate, Potassium bicarbonate and Ascorbic acid are effective against early blight in potato as compared to control one, however, highest percent inhibition of conidial germination $(88.89 \%)$ in vitro, percent disease reduction $(42.10 \%)$ and yield (25.31 t/ha) was recorded when Oxalic acid was used for the management of early blight disease in potato.

\section{References}

Bag, T.K. and Sinha A.K. 1997. Control of stem rot of soybean incited by Sclerotium rolfsii through metal salts. Indian Phytopath 50 (3): 350-357.

Chester, F. D. 1892. Diseases of the round potato and their treatment. Annual Report of the Delaware College Agricultural Experimental Station 5: 67-70.

Dasgupta S., Raj S. K. and Das S. 2000. Control of collar rot disease of groundnut caused by Aspergillus niger by seed soaking with non-conventional chemicals. Indian Phytopathol 53 (2):227-229.

Dhingra, O. D. and Sinclair, J. B. 1995. Basic Plant Pathology Methods. $2^{\text {nd }}$ edition. Boca Raton FL. CRC Press.

Ellis, J. B. and Martin, G. B. 1882. Macrosporium solani. $E \& \&$. American Naturalist 16: 1003.

Faboya, O., Ikotum, T. and Fatoki, O.S. 1983. Production of oxalic acid by some fungi in infected tuber. Zallg Microbio 24: 621-624. 
Foolad, M. R., Ntahimpera, N., Christ. B. J. and Lin, G. Y. 2000. Comparison of field greenhouse, and detached-leaflet evaluations of tomato germ plasm for early blight resistance. Plant Disease 84:967-972.

Gomez, K. A. and Gomez, A. A. 1984. Statistical procedures for agricultural research. $2^{\text {nd }}$ edition. John Wiley \& Sons, Inc. New York, USA.

Hussain, T. 2016. Potatoes: Ensuring Food for the Future. Adv Plants Agric Res 3(6): 117.

Jones, L. R. 1893. The new potato disease or early blight. Vermont Agricultural Experimental Station Bulletin 6: 66-70.

Maity, M.K., Raj, S. K. and Das, S. 2005. Management of leaf spot (Cercospora arachidicola and Phaeoisariopsis personata) of groundnut by seed treatment with non-conventional

chemicals. Indian Journal of Agriculture Sciences 75: 452-453.

Mitra, P. and Chowdhury, A. P. 2001. Protection of soyabean seedling from Sclerotium rot by seed treatment with alternative chemical agents. $J$ Mycopathol Res 39 (1): 35-38.

Monthly Report. 2017. Horticulture Statistics Division, Department of Agriculture, Cooperation and Farmer Welfare, Ministry of Agriculture and Farmer Welfare, GoI.

Olivier, C., Halseth, D. E., Mizubuti, E.S. G and Loria, R. 1998. Postharvest application of organic and inorganic salts for suppression of silver scurf on potato tubers. Plant Disease 82(2): 213217.

\section{How to cite this article:}

Dibakar Panda, Ashish Chakraborty, Ritesh Kumar and Saurav Govind Rao. 2018. Use of NonConventional Chemicals against Early Blight of Potato (Solanum tuberosum) Caused by Alternaria solani. Int.J.Curr.Microbiol.App.Sci. 7(06): 1046-1053.

doi: https://doi.org/10.20546/ijcmas.2018.706.124 